\title{
Estimating the Two Graph Dextran-Stearic Acid-Spermine Pol- ymers Based on Iron Oxide Nanoparticles as Carrier for Gene Delivery
}

\author{
Mehrnoosh Kazemi Ashtiyani ${ }^{1}$, Behnam Hajipour-Verdom ${ }^{1}$, Mohammad Satari' ${ }^{2}$, Parviz Abdolmaleki ${ }^{1}{ }^{*}$, Saman \\ Hosseinkhani ${ }^{3}$
}

Department of Biophysics, Faculty of Biological Sciences, Tarbiat Modares University, Tehran, 14115-154, Iran; mehrnushkaz@gmail.com; $\underline{\text { b.hajipour@modares.ac.ir; parviz@modares.ac.ir. }}$

2 Department of Biology, Faculty of Sciences, Malayer University, Malayer, 65719-95863, Iran; m.satari66@yahoo.com.

3 Department of Biochemistry, Faculty of Biological Sciences, Tarbiat Modares University, Tehran, 14115-154, Iran; saman_h@modares.ac.ir.

* Correspondence: parviz@modares.ac.ir; Tel.: (+98 218288 3404; +98 218288 4717)

\begin{abstract}
Non-viral gene carriers because of their limited side effects, biocompatibility, simplicity and taking the advantages of electrostatic interactions have shown noticeable potential in gene delivery. The low transfection rate of non-viral vectors under physiological conditions is a significant issue. Here, the aim of this study was to investigate the efficacy of hydrophilic and hydrophobic groups on gene carriers such as two synthesized amphiphilic polymer of dextran-stearic acidspermine (DSASP) with verified lipid and amine conjugations that associated with $\mathrm{Fe}_{3} \mathrm{O}_{4}$ superparamagnetic nanoparticles to promote the target delivery and decrease the transfection time using static magnetic field. Our findings illustrate that magnetic nanoparticles are spherical with positive surface charges and superparamagnetic behaviors. The DSASP-pDNA/MNPs offered a strong pDNA condensation, protection against DNase degradation, significant cell viability in HEK 293T cells and. Although conjugations of spermine play a critical role in transfection efficiency, amphiphilic polymer with more derivatives of stearic acid showed better transfection yields. Therefore, DSASP amphiphilic magnetic carriers offer new insights for gene delivery due to the amine contents and ameliorate the uptake of complexes via cell membrane based on its hydrophilic surface.
\end{abstract}

Keywords: Gene delivery; Non-viral carrier; Dextran-stearic acid-spermine; Iron oxide nanoparticles; Static magnetic field.

\section{Introduction}

The undeniable side effects of traditional approaches have been implemented for cancer therapy such as surgery, chemotherapy and radiotherapy, which lead to valuable research in the field of gene therapy to avoid killing some normal cells, DNA damaging, emergence of secondary cancer, etc. Small particles are sent to tumor cells based on selective treatment to repair and modify missing cellular functions and genes, which prevent the expression of unwanted genes production before translation and regulate proteins [13].

The ideal gene delivery system must comprise fundamental criteria. First, attending to the importance of cellular uptake of nanocarriers and prevention of charge repulsion in the delivery process, polycations should be able to neutralize negative charge of DNA due to negative charges of plasma membrane [4,5]. The relationship of cellular clearance and size of nanoparticles could be assumed as a second parameter. Additionally, biocompatibility and immunogenicity are other substantial parameters. Therefore, nanoparticles 
should be stabled enough in the biological conditions not only before reaching the targeted-tumor cells, but also in the process of expression in the nucleus [1,6]. Moreover, opsonization based on the surface characteristics of nanoparticles, is deemed as a crucial factor in their stabilization [7].

The carriers are classified into two major groups of viral and non-viral vectors, which each represent the gene delivery process as transduction and transfection, respectively [8]. Although the efficiency of viral vectors have been shown in clinical research, it is hard to elicit an effective therapeutic response due to their inherited substantial disadvantages like difficult production process, risk of mutagenesis and limited cargo capacity [9]. Furthermore, immunogenic responses to viruses will intensively suppress the effect of viral vectors and subsequently restrict the rate of transduced vectors to targeted cells [10]. Nonviral vectors are able to circumvent some of delivery-associated limitations of viral vectors with some constructive biological advantages such as low immune responses, affordable cost of production in large scale, safety or non-cytotoxicity, and also more targeted transfection through designed-surface ligands. However, in vivo transfection efficiency of nonviral vectors is lower than viral vectors [3,11].

Polymeric and cationic lipids as non-viral carriers condense the string-like DNA into nanoscale dimension to become appropriate for cellular uptake [12]. Polycations like polysaccharides have possible opportunities in the changing or improving physicochemical attributes of their efficacy through power of binding, reaching the least toxicity and impressive cellular release $[1,13]$. The polycations are all polyamines that contain the first, second, third, or fourth amine groups [1]. Polymeric macromolecules with high cationic charges can operate as an endosomal buffering system in gene delivery which suppresses the endosomal enzymes activity and prevents degradation and accumulation of trappedDNA molecules in cytosol $[1,14]$.

Dextran is a linear and non-polyelectrolytes polysaccharide, consists of a-1,6 glycosidic linkages and also few branch of a-1, 3 glycosidic linkages [15-17]. Additionally, the presence of this neutral surface alongside other properties like low immunogenicity, water-solubility, lower rate of plasma protein absorption and more specific cellular uptake lead to their widespread usage in the different gene transfection of tumor targeted-therapy $[15,18]$. Spermine is known as a natural tetra-amine, which involves in two primary and two secondary amino groups [19]. Azzam et al., shown that only polycations of dextran grafted with spermine has high efficiency in the in vitro cells transfection between 300 cationic polysaccharides in different molecular weights [20].

The serum medium has high inhibitory effects on the transfection rate of water-soluble dextran-spermine-DNA polymer up to $95 \%$ based on high hydrophilic property. Moreover, covalent attachment of hydrophobic residues to some dextran-spermine NH2 moieties could ameliorate the transfection efficiency in the serum containing media [3,21]. In addition, based on the resemblance of structure of hydrophobic molecules with the plasma membrane, amphiphilic modifications of polycations tend to enhance or even ease carriers' cellular uptake via endocytosis [21]. Stearic acid is a saturated-fatty acid, with appropriate biocompatibility and lower cytotoxicity has been utilized a lot in delivery systems. Amphiphilic dextran-stearic acid-spermin (DSASP) preparation takes place through esterification between the carboxyl group of stearic acid and hydroxyl group of the glucose units in dextran $[15,22]$.

Magnetofection is known as an effective approach for transfection to overcome restrictions like inactivation of some carriers under cell culture conditions and acceleration of diffusion [8,23]. Superparamagnetic iron oxide $\left(\mathrm{Fe}_{3} \mathrm{O}_{4}\right)$ nanoparticles are cubic inverse spin structures with well discretion in original solvent that are considered assubstantial magnetic materials based on widespread usage in various biomedical applications. These often undergo surface changes or are coated with polymers to become more appropriate in biological conditions to be prolonged in physical conditions and reduction of complex agglomeration [17,24-26].

In this study, we have investigated the aspects of magnetic DSASP polymers based on magnetofection for gene delivery in the HEK 293T cells (Figure 1). $\mathrm{Fe}_{3} \mathrm{O}_{4}$ nanoparticles 
are encapsulated inside two amphiphilic DSASP polymers with different grafted rates of stearic acid and spermine, which condensed pDNA well. Our findings show that interaction of DSASP@pDNA with $\mathrm{Fe}_{3} \mathrm{O}_{4}$ represents a novel biodegradable and biocompatible non-viral carrier which can be utilized for gene delivery.

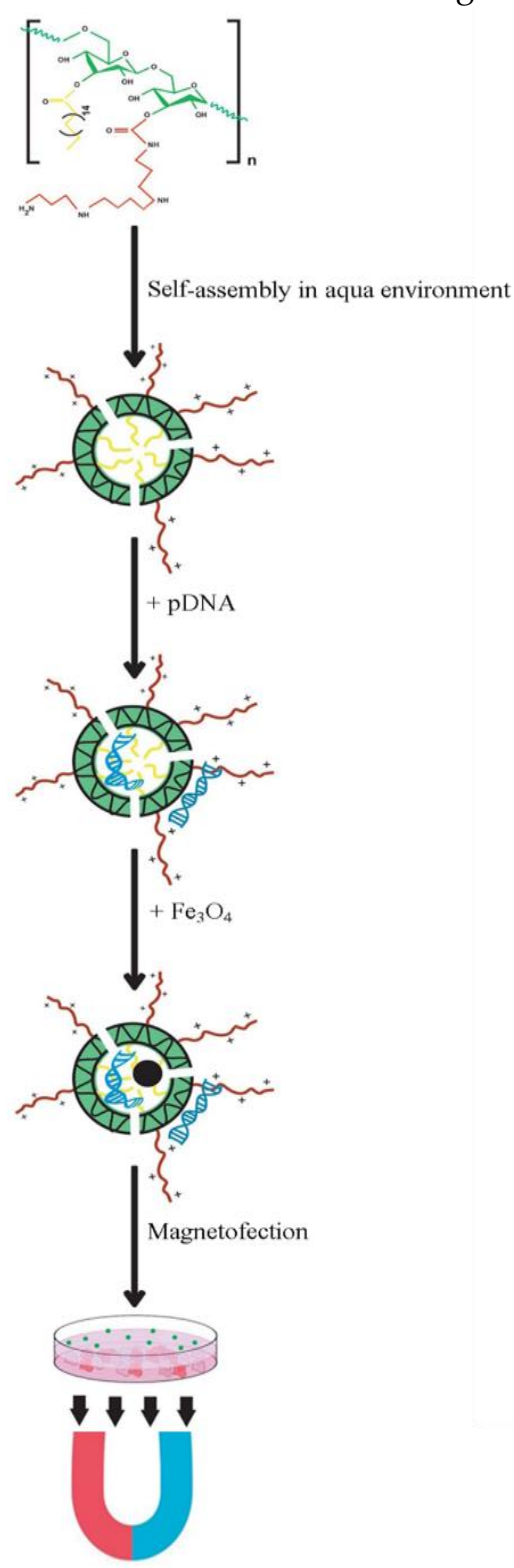

Figure 1. The overview of amphiphilic polymer of dextran-stearic acid-spermine (DSASP) used to transfer nucleic acid via $\mathrm{Fe}_{3} \mathrm{O}_{4}$ encapsulation in the magnetofection process.

\section{Materials and Methods}

\subsection{Chemical reagents}

Dulbecco's modified eagle's medium (DMEM) and fetal bovine serum (FBS) were purchased from Gibco. Penicillin-streptomycin and trypsin-EDTA were obtained from Bioidea. The $25 \mathrm{kDa}$ branched polyethylenimine (PEI) and (3-(4,5-dimethylthiazol-2-yl)-2,5diphenyltetrazolium bromide (MTT) were obtained from Sigma-Aldrich. $\mathrm{FeCl}_{3} \cdot 6 \mathrm{H}_{2} \mathrm{O}$, $\mathrm{FeSO}_{4} .7 \mathrm{H}_{2} \mathrm{O}$ and $\mathrm{NaOH}$ were purchased from Merck. Dimethyl sulfoxide (DMSO) was obtained from Daejung Chem., Korea. Two prepared polymers of dextran-stearic acidspermine polymers (DSASP) were obtained from Dr. Ebrahim Vasheghani-Farahani lab. 
Chemical co-precipitation method is defined as one of the $\mathrm{Fe}_{3} \mathrm{O}_{4}$ nanoparticles synthesized protocol [27]. In brief, $\mathrm{FeCl}_{3} .6 \mathrm{H}_{2} \mathrm{O}$ and $\mathrm{FeSO}_{4} .7 \mathrm{H}_{2} \mathrm{O}$ with a molar ratio of 2:1 were mixed under continuous stirring and nitrogen gas bubbling to inhibit oxidation. Subsequently, to reach the $\mathrm{pH}$ up to $10, \mathrm{NaOH}(2.0 \mathrm{M})$ was slowly added into the mixture under continuous stirring. Moreover, the black precipitate as a result of $\mathrm{NaOH}$ addition, indicates the formation of $\mathrm{Fe}_{3} \mathrm{O}_{4}$ nanoparticles. Then, the mixture was vigorously stirred for $15 \mathrm{~min}$ and incubated at $70{ }^{\circ} \mathrm{C}$ for $30 \mathrm{~min}$, after that it was cooled down at room temperature. $\mathrm{Next}, \mathrm{Fe}_{3} \mathrm{O}_{4}$ nanoparticles were magnetically separated and frequently washed by deionized-water and ethanol solution to remove the impurities. Finally, MNPs were dried in an oven at $60{ }^{\circ} \mathrm{C}$ and collected by magnetic separation and stored under $\mathrm{N}_{2}$ gas condition [28].

\subsection{Plasmid purification}

Plasmid DNA (pDNA) used in this study was pDB2 plasmid encoding luciferase, was propagated and isolated from DH5a E. coli overnight. Qiagen Maxi kit-25 (Qiagen K.K., Tokyo, Japan) was applied for extraction and purification of pDNA. The concentration and purification of pDNA was measured using Nanodrop (Thermo, Wilmington, DE, USA) at an absorbance ratio of $260 / 280 \mathrm{~nm}$ ranging from 1.9 to 2.2.

\subsection{Preparation of polymer-based magnetic complexes}

The pDNA $(1 \mu \mathrm{g} / \mu \mathrm{l})$ and DSASP polymer at different mass ratios were diluted in deionized-water and incubated for $30 \mathrm{~min}$ at room temperature to from DSASP-pDNA complexes. Then, $1 \mu \mathrm{g} / \mu \mathrm{l} \mathrm{Fe}_{3} \mathrm{O}_{4}$ magnetic nanoparticles (MNPs) were added to the mixture of DSASP-pDNA complexes and reincubated for extra $30 \mathrm{~min}$.

\subsection{Characterization of magnetic nanoparticles and complexes}

The size and charge of MNPs and complexes were performed by dynamic light scattering (DLS). The size distribution and zeta potential were evaluated with a Zetasizer Nano-ZS instrument, Model ZEN3600 (Malvern Instruments, UK). Briefly, the dispersions of $\mathrm{Fe}_{3} \mathrm{O}_{4}$ were sonicated for $30 \mathrm{~s}$ in deionized-water and then incubated with DSASPpDNA complex as previously mentioned. The particle size was measured in the scattering angle $173^{\circ}$ at $25^{\circ} \mathrm{C}$. The zeta potential was measured using a universal zeta dip cell. DLS measurements were taken for DSASP-pDNA/ $\mathrm{Fe}_{3} \mathrm{O}_{4}$ in the presence of increasing concentrations of DSASP. In addition, scanning electron microscopy (SEM) analysis was carried out to indicate the morphology and the size of both MNPs and complexes. Moreover, the magnetic properties of dried-SPIONs and DSASP-Fe $\mathrm{O}_{4}$ were measured at a maximum applied field of $10 \mathrm{kOe}$ using VSM 7300 vibrating sample magnetometer (VSM) (Lakeshore, USA). Furthermore, the chemical component and molecular vibrations of samples were analyzed by Fourier transform infrared spectroscopy (FTIR, Thermo Scientific Nicolet IR100, Madison, USA) using KBr pellet. Three scans per spectrum (400-4000 $\mathrm{cm}^{-1}$ ) at the resolution of $4 \mathrm{~cm}^{-1}$ were measured for dried samples of $\mathrm{Fe}_{3} \mathrm{O}_{4}$, DSASP and DSASP-Fe $\mathrm{O}_{4}$ mixed with $\mathrm{KBr}$ and made into pellets. The $6 \mathrm{mg} / \mathrm{ml}$ DSASP-Fe $\mathrm{O}_{4}$ was used in SEM, VSM and FTIR measurements.

\subsection{Gel retardation assay}

The gel retardation or electrophoretic mobility shift assay is utilized to evaluate the DNA interaction with complexes [29] and ensure about formation of ternary complexes of pDNA- DSASP-Fes $\mathrm{O}_{4}$. DNA molecules migrate from the negative electrode towards the positive electrode. Moreover, addition of the small molecules such as DSASP to pDNA, the mobility will be restricted through the gel based on the emergence of electrostatic interaction between pDNA and polymer [30]. DNA condensation and mobility after binding with DSASP-Fe $\mathrm{O}_{4}$ complex was identified by gel retardation assay. Different weight-mixing ratios of DSASP-pDNA/Fe3O $\mathrm{F}_{4}(1,2.5,5,10,25,50$ and 100) were prepared while the content of DNA to $\mathrm{Fe}_{3} \mathrm{O}_{4}$ was kept at $1 \mu \mathrm{g} / \mu \mathrm{l}$ and incubated at $37^{\circ} \mathrm{C}$ for $15 \mathrm{~min}$. After that, $8 \mu \mathrm{L}$ of mixture suspension was analyzed by $1 \%$ agarose gel electrophoresis $(90 \mathrm{~V}, 45 \mathrm{~min})$. Naked-pDNA was utilized as a control group. The gel was stained in 0.5 
$\mathrm{mg} / \mathrm{ml}$ ethidium bromide for $30 \mathrm{~min}$ to visualize the localization of pDNA by UV illumination.

\subsection{Serum stability assay}

In the process of gene transfection, the usage of naked-DNA due to effects of nucleases and reticuloendothelial system cannot be possible. So, the necessity of appropriate vectors for protecting DNA play a crucial role against the enzymatic conditions. Moreover, to have an efficient gene delivery system especially in the in vitro, genetic materials' carrier should protect DNA in front of serum enzyme during gene delivery, and also minimize the time association of pDNA with blood serum, which was investigated by DNaseI activity at weight ratio of 10 in the gel electrophoresis. Briefly, $6.5 \mu \mathrm{l}$ of each complex was exposed to $0.75 \mu \mathrm{l}$ of DNaseI (Promega, USA) in the final volume of $15 \mu \mathrm{L}$ for $15 \mathrm{~min}$ at $37^{\circ} \mathrm{C}$. The reaction was inactivated followed by transferring complex into $-20{ }^{\circ} \mathrm{C}$. After the addition of $10 \%$ sodium dodecyl sulfate (SDS) to the solution, pDNA was released from complex and subsequently $8 \mu \mathrm{l}$ of each sample comprising $3 \mu \mathrm{g}$ DNA that was analyzed by $1 \%$ agarose gel electrophoresis $(90 \mathrm{~V}, 45 \mathrm{~min})$. The integrity of released-pDNA from the complex was compared with the naked-pDNA as control.

\subsection{Cell Culture}

The human embryonic kidney 293T cell line (HEK 293T) was obtained from Pasteur Institute of Iran (IPI). The cells were maintained in Dulbecco's Modified Eagle's Medium (DMEM) in the neutral PH (7.2-7.4) supplemented with $10 \%$ (v/v) heat-inactivated $\left(50^{\circ} \mathrm{C}\right.$, $30 \mathrm{~min}$ ) fetal bovine serum (FBS) and $2 \mathrm{mM}$ glutamine, $100 \mathrm{units} / \mathrm{mL}$ of penicillin and 100 $\mathrm{mg} / \mathrm{mL}$ of streptomycin at $37^{\circ} \mathrm{C}$ and $5 \% \mathrm{CO}_{2}$ in a humidity incubator. The cells were then trypsinized (0.025\% trypsin, $0.02 \%$ EDTA) after they were grown up to $70-80 \%$ confluent. Prior to treatments, cells were allowed to reattach overnight.

\subsection{Cell viability assay}

The viability of cells which are treated by nanoparticles were measured by MTT assay. This is a colorimetric assay based on ability of viable cells to reduce the water-soluble yellow tetrazolium salt (3-(4,5-dimethylthiazol-2-yl)-2,5-diphenyltetrazolium bromide (MTT)) by mitochondrial $\mathrm{NAD}(\mathrm{P}) \mathrm{H}$-dependent oxidoreductase enzyme (succinate dehydrogenase) to purple insoluble formazan crystal. The HEK 293T cells were seeded into 96well cell culture plates (SPL Life Sciences Co., Ltd. Korea) at the final concentration of $10^{4}$ cells/well and incubated in $100 \mu \mathrm{L}$ of DMEM containing 10\% FBS and allowed to attach overnight. Then, cells were treated in the fresh supplemented DMEM with $10 \%$ FBS by DSASP-pDNA/ $/ \mathrm{Fe}_{3} \mathrm{O}_{4}$ complexes including $1 \mu \mathrm{g} / \mu \mathrm{L}$ concentration of $\mathrm{Fe}_{3} \mathrm{O}_{4}$ nanoparticles and pDNA, and different weight-ratio of $\operatorname{DSASP}(0.5,1,2.5,5,10,20,25,50$ and 100) in presence and absence of homogenous static magnetic field (SMF, $20 \mathrm{mT}$ ) for $30 \mathrm{~min}$. After 24 and $48 \mathrm{~h}$ treatments, the media was removed and MTT solution $(0.5 \mathrm{mg} / \mathrm{ml}$ in FBS-free DMEM) was added and incubated at $37^{\circ} \mathrm{C}$ for extra $4 \mathrm{~h}$ in the dark. After that, the media was removed and $100 \mu \mathrm{L}$ DMSO was added to each well. Finally, the absorbance of formazan intensity was quantified by a microplate reader (uQuant MQX200, BioTek, USA) at $570 \mathrm{~nm}$.

\subsection{Magnetofection}

In this study, the gene delivery process, the magnetic ternary complexes were transferred to cells. The complexes comprised the pDNA and MNPs in the similar mass ratio of $1 \mu \mathrm{g}$. The extracted pDNA encoding the luciferase reporter gene that handles based on kinase activity, which converts luciferin to oxyluciferin and light using ATP. The ATP is converted to AMP and release the energy of the phosphate bonds in the form of light that was measured by luminometer [31]. The intensity of light indicates the activity of luciferase being equivalent to the amount of delivered nucleic acid to the cells. Briefly, $5 \times 10^{4}$ cells/well of HEK 293T cells were seeded in the 24 well cell culture plates and allowed to attach overnight. Then, $1 \mu \mathrm{g} / \mu \mathrm{l}$ pDNA was mixed with a DSASP solution at various mass ratios $(0.5,1,2.5,5,10,20,25,50$ and 100) and incubated for $15 \mathrm{~min}$. After that, the prepared-complexes gently were mixed with $1 \mu \mathrm{g} / \mu \mathrm{Fe} \mathrm{Fe}_{4}$ nanoparticles and reincubated for 
extra 15 min. Each prepared complex's DSASP-pDNA/Fe $\mathrm{O}_{4}$ were diluted with FBS-free DMEM to a final volume of $300 \mu \mathrm{L}$ and incubated at room temperature for extra $30 \mathrm{~min}$. Next, polyplex solutions were added to cells in presence and absence of homogenous SMF $(20 \mathrm{mT})$ at $37^{\circ} \mathrm{C}$ for $30 \mathrm{~min}$. After that, the media was replaced with DMEM containing $10 \%$ FBS, and cells were incubated for $48 \mathrm{~h}$. Moreover, the $4.8 \mu \mathrm{g}$ PEI at N:P ratio of 12 was utilized as control. Then, the media was completely removed and cell lysates were analyzed for luciferase activity that is followed by injection of assay buffer to a tube containing cell lysate and luminescence was evaluated using a luminometer (Berthold detection systems, GmbH, Germany).

\subsection{Statistical Analysis}

GraphPad Prism v5.07 (GraphPad Software Inc., San Diego, CA) was used for statistical analysis and data graphing. We applied one-way followed by post-hoc analysis using Newman-Keuls multiple comparison test to compare between independent variables. The error bars represented the mean \pm standard deviation (mean \pm SD) of at least three independent experiments $(n=3)$. P-values including ${ }^{*} p<0.05 ;{ }^{* *} p<0.001 ;{ }^{* * *} p<0.0001$ were considered as a statistical significance difference.

\section{Results}

\subsection{Formation of $M N P s$ and $D S A S P-p D N A / M N P S$}

The formation of ternary nanocomplexes is fundamental in transferring nucleic acids comprising magnetic cores with polymeric shells that are conjugated to pDNA. In the delivery systems, the size of nanocarriers have significant roles that were obtained from DLS about $62 \mathrm{~nm}$ for the synthesized $\mathrm{Fe}_{3} \mathrm{O}_{4}$ and 100-300 nm for the SPIONs formulated in DSASP-pDNA complex at weight ratios of 10-100 w/w (Figure 2a,c). The zeta potential of the superparamagnetic iron oxide nanoparticles was $-27 \mathrm{mv}$ (Figure $2 \mathrm{~b}$ ). The stronger negative surface charge distribution of nanoparticles can facilitate the electrostatic interaction with positive charge particles. Additionally, results demonstrated that increasing the positive charge and decreasing the particle size as a result of rise in the mass ratio of $\operatorname{DSASP}(0.5,1,2,5,5,10,25,50,100)$ at the a concentration of $\mathrm{Fe}_{3} \mathrm{O}_{4} / \mathrm{pDNA}(1 \mathrm{mg} / \mathrm{ml})$, can efficiently affect the electrostatic interactions with pDNA and lead to more condensed molecules (Figure 2c,d). Successful synthesis of DSA6SP-pDNA/Fe3 $\mathrm{O}_{4}$ nanoparticles sustained due to the positive zeta potential of $+35 \mathrm{mv}$ value at weight rate of $50 \mathrm{w} / \mathrm{w}$. In addition, DSASP 6 and 8 have a relative difference in amine contents as a result of divers' conjugation of stearic acid, in which the amount of $20 \%$ and $15 \%$ were evaluated for their hydrophobic part, respectively.

Boosting the graph rate of stearic acid can decrease the micelles particle size. There is a harmony with this phenomenon that the ratio of hydrophobic to hydrophilic chain length, remarkably impresses the particle size in linear amphiphilic polymers (Figure 2c). So, smaller particle size with higher surface/volume ratios will have higher zeta potential, which could efficiently surround negative charge of nucleic acids (Figure 2d). Negative surface charge of DSASP-pDNA/ $\mathrm{Fe}_{3} \mathrm{O}_{4}$ complexes at w/w ratio below 10 , were gradually transferred into positive potential as result of an increase in $\mathrm{w} / \mathrm{w}$ rate of polymer. Furthermore, in this study the negative surface charge almost up to $5 \mathrm{w} / \mathrm{w}$ demonstrated insufficient formation of complexation between polymer and DNA though electrostatic repulsion which indicated complex inability to condense nucleic acids negatively charged phosphate backbone properly (Figure 2d) [12,32].

As shown in Figure 3a, the SEM image of MNPs declares a homogeneously spherical shape for $\mathrm{Fe}_{3} \mathrm{O}_{4}$ particles with diameter around 12-18 nm, which has proper agreement with the result of DLS assay. Obtained SEM results also represent roughly spherical form for agglomeration of DSASP-Fe $\mathrm{O}_{4}$ nanoparticles with desirable dispersibility and no significant size difference in comparison with $\mathrm{Fe}_{3} \mathrm{O}_{4} \mathrm{MNP}$ (Figure 3b). Therefore, due to optimum size of delivery vectors from 50 to $100 \mathrm{~nm}$ [12], the MNPs derived from DSASPpDNA/ $\mathrm{Fe}_{3} \mathrm{O}_{4}$ seems to be efficient in gene delivery. Size comparison between SEM imag- 
ing and zetasizer measurement is attributed to dried and hydrated state of samples, respectively. It means that the DLS information represents the hydrodynamic size of nanoparticles being naturally larger than their actual size [33].

Moreover, VSM was used to investigate the magnetic behavior of nanoparticles and the formation of DSASP-Fe $\mathrm{O}_{4}$ complexes. The maximum size for superparamagnetic behavior is generally taken to be almost $30 \mathrm{~nm}$ [34]. The hysteresis loops of bare $\mathrm{Fe}_{3} \mathrm{O}_{4}$ and coated MNPs of DSASP-Fe $\mathrm{O}_{4}$ was shown in Figure 3c,d. Reduction in hysteresis magnetization from plateau level to zero was remarkably shown at room temperature ( 298 K) for both curves through removal of MFs confirming their superparamagnetic property. In addition, the magnetic saturation of MNPs complexes is estimated to be $30.160 \mathrm{em} \mu \cdot \mathrm{g}^{-1}$, being lower than bulk $\mathrm{Fe}_{3} \mathrm{O}_{4}$ at $65.3 \mathrm{em} \mu \cdot \mathrm{g}^{-1}$. The lower rate of magnetic saturation of DSASP-Fe을 $\mathrm{O}_{4}$ compared to $\mathrm{Fe}_{3} \mathrm{O}_{4}$ could be attributed to the attachment of DSASP to nanoparticles. Indeed, cationic surface spines of polymer as modification, affect the core spin of $\mathrm{Fe}_{3} \mathrm{O}_{4}$ from along the MFs that decrease the complex saturation magnetization values [35].

The IR spectrum being obtained from the FTIR spectrometer is located in the mid-IR region (666-4000 $\left.\mathrm{cm}^{-1}\right)$. Considering the mid-IR region, many functional groups' transition energy due to their alternation in vibrational energy state could be estimated to determine whether specific functional groups exist in the structure of molecules [36]. The FTIR spectrum shows striking information on the chemical structure of $\mathrm{Fe}_{3} \mathrm{O}_{4}$ nanoparticle and DSASP-Fe3 $\mathrm{O}_{4}$ complexes in the region of $400-4000 \mathrm{~cm}^{-1}$ (Figure 3e). The first gradual absorption pick at $3413.89 \mathrm{~cm}^{-1}$ originated from strong stretching vibrations of hydrogen band with hydroxyl groups $(\mathrm{OH})$ that were absorbed by the sample from the medium. The evaluated peak at $1617 \mathrm{~cm}^{-1}$ is attributed to the $\mathrm{O}-\mathrm{H}$ bending [37]. In addition, the second absorption peak at $567.06 \mathrm{~cm}^{-1}$ is assigned to $\mathrm{Fe}-\mathrm{O}$ bond in $\mathrm{Fe}_{3} \mathrm{O}_{4}$ nanoparticles which indicates the synthesization of nanoparticles. Changing the peak location of $\mathrm{Fe}-\mathrm{O}$ from $567 \mathrm{~cm}^{-1}$ to $583 \mathrm{~cm}^{-1}$ showed relative interaction of stearic acid with SPIONs. Although the intensity of this peak replacement was expected to be stronger, decline in $\mathrm{Fe}_{3} \mathrm{O}_{4} \mathrm{ab}$ sorption peak spectrum, demonstrated its sufficient entrapment by biopolymer. Moreover, decline in $\mathrm{COO}^{-}$vibration from 1709.29 to 1699.78 could be considered as another evidence for stearic acid interactions. Furthermore, both binding groups of $\mathrm{C}-\mathrm{N}$ at wavelength peak of 1650-1620 $\mathrm{cm}^{-1}$ and noticeable decline in absorption peak of 580 to $631 \mathrm{~cm}^{-}$

1 in $\mathrm{Fe}_{3} \mathrm{O}_{4}$ could be related to dextran-spermine entrapment $[18,38,39]$. So, results showed a successful synthesis of MNPs grafted to polymers. 
Size Distribution by ittensty

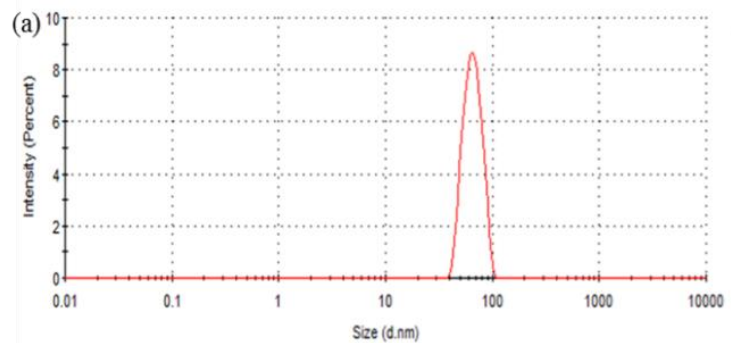

$\square \mathrm{DSA}_{8} \mathrm{SP}-\mathrm{pDNA} / \mathrm{MNPs}$

(c) $\left.{ }^{600}\right] \square \mathrm{DSA}_{6} \mathrm{SP}-\mathrm{pDNA} / \mathrm{MNPs}$

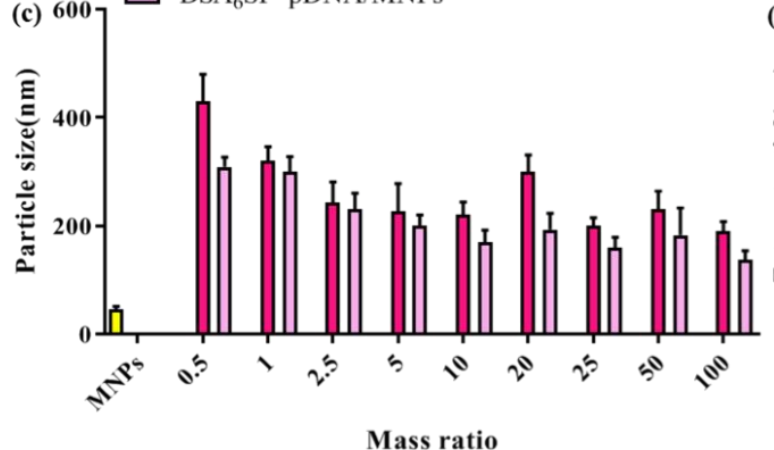

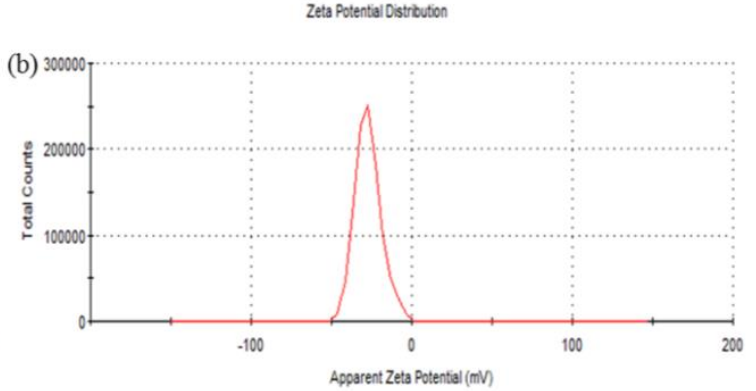

$\square \mathrm{DSA}_{8} \mathrm{SP}-\mathrm{pDNA} / \mathrm{MNPs}$

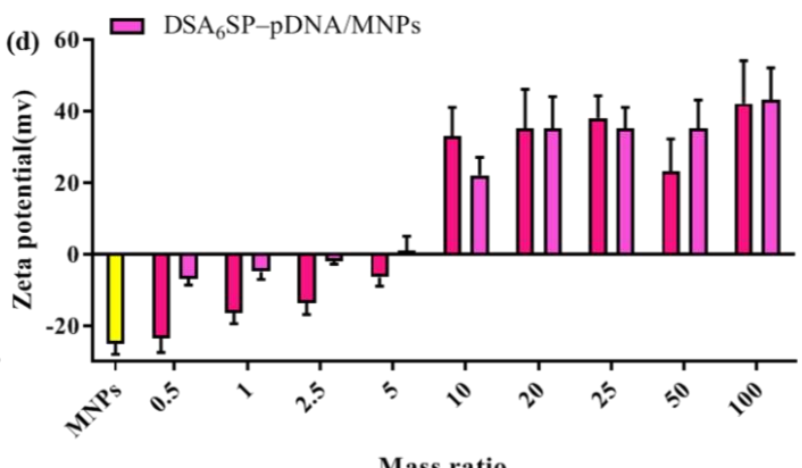

Figure 2. The $(\mathbf{a}, \mathbf{b})$ size and $(\mathbf{c}, \mathbf{d})$ zeta potential of $\mathrm{Fe}_{3} \mathrm{O}_{4}$ nanoparticle (MNPs) and dextran-stearic acid-spermine (DSASP)-pDNA/MNPs complexes were evaluated at different mass ratios. 

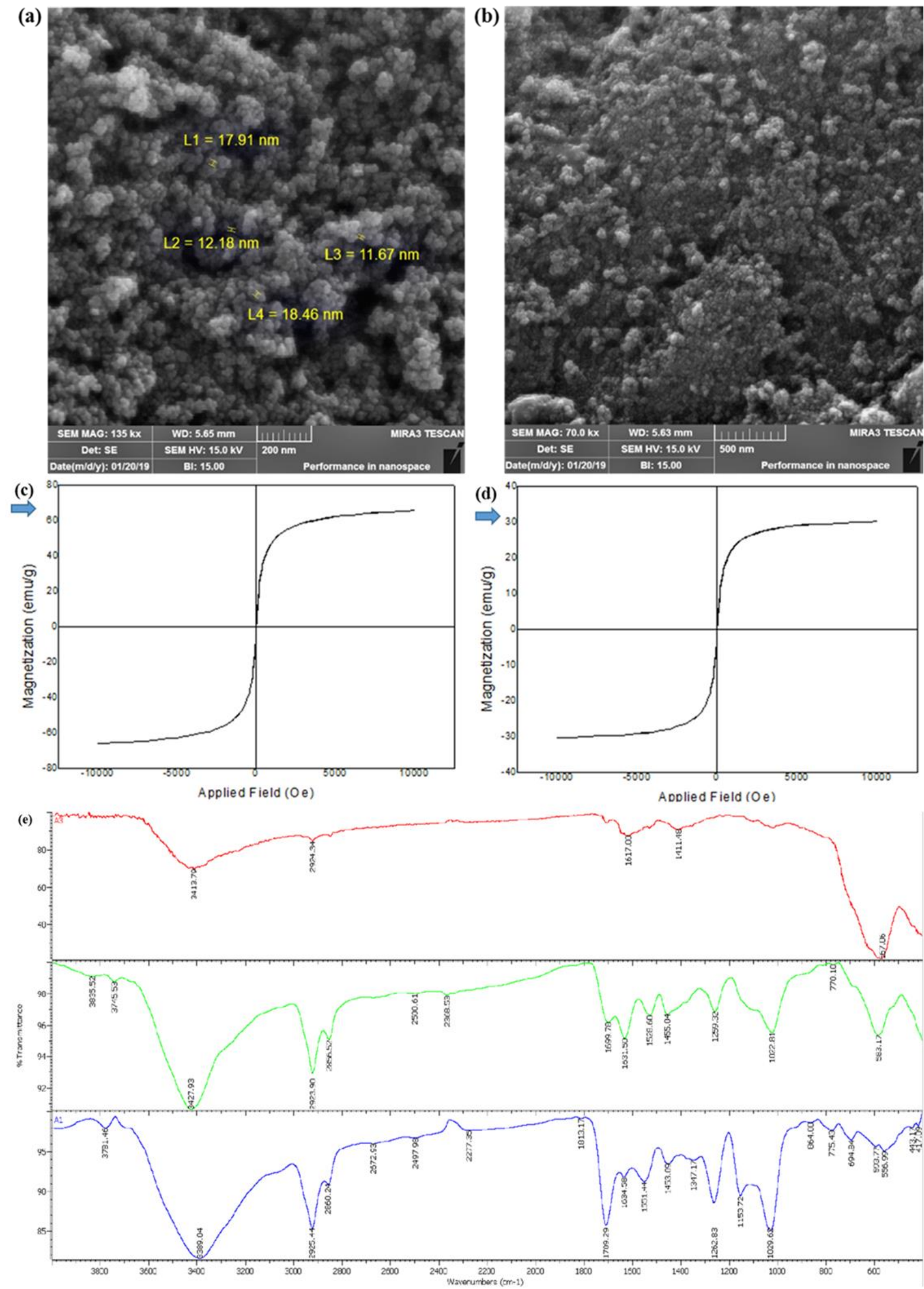

Figure 3. Charactriaztion of synthesised MNPS. The SEM images of (a) $\mathrm{Fe}_{3} \mathrm{O}_{4} \mathrm{MNPs}$ and (b) dextran-stearic acid-spermine (DSASP)@Fes $\mathrm{O}_{4}$. The vibrating sample magnetometer (VSM) shows superparamagnetic property of MNPs based on no hysteresis loop, $\mathrm{Hc}=0$ Oe (c) $\mathrm{Fe}_{3} \mathrm{O}_{4}$ nanoparticles and (d) DSASP-Fe3 $\mathrm{O}_{4}$ nanocomplexes. (e) FTIR spectra of $\mathrm{Fe}_{3} \mathrm{O}_{4}$ nanoparticles (red peak) DSASP polymer (blue peak) and the magnetic nanocomplex of DSASP-Fe3 $\mathrm{O}_{4}$ (green peak). 


\subsection{Estimating the protection capability of nanocomplexes}

Protection capability for both 6 and 8 DSASP polymers in different complexes charge and mass ratios at $1,2.5,5,10,20,25,50,100 \mathrm{w} / \mathrm{w}$ were prepared in $1 \%$ agarose gel electrophoresis. As shown in Figure $4 \mathrm{a}, \mathrm{b}$, for both of DSA ${ }_{6} \mathrm{SP}$ and DSA ${ }_{8} \mathrm{SP}$ at mass ratio above $1 \mathrm{w} / \mathrm{w}$, with increasing concentration, no migration was observed for complexes since they remained in the well. Turning to $1 \mathrm{w} / \mathrm{w}$ for both polymer weak interactions was shown between DNA and DSASP and the positive charge of complexes could not completely prevent the plasmid from migration toward the positive electrode. In addition, at this mass ratio compared to polymer 8 , it seemed that DSA6SP had better electrostatic interaction with DNA due to the appearance of a more inconspicuous bond on agarose gel. Therefore, these differences indicated that in equal proportions of these polymers, the $\mathrm{DSA}_{6} \mathrm{SP}$ ability in pDNA capsulation was greater than DSA $8 \mathrm{SP}$ polymer. The instability of pDNA in presence of DNaseI was incubated with pDNA-DSASP-Fe $\mathrm{O}_{4}$ ternary complexes. As seen in Figure 4c,d, the fragment smear at the bottom of agarose gel indicated that naked DNA is degraded within $30 \mathrm{~min}$ while duplex and ternary complexes with pDNA were completely protected from enzymatic degradation. Furthermore, the plasmid bands after the addition of SDS to incubated complexes with DNaseI indicates the pDNA complexes with DSASP or DSASP-Fe3 $\mathrm{O}_{4}$ particles remained intact whereas naked $\mathrm{pDNA}$ was almost digested. 
(a)
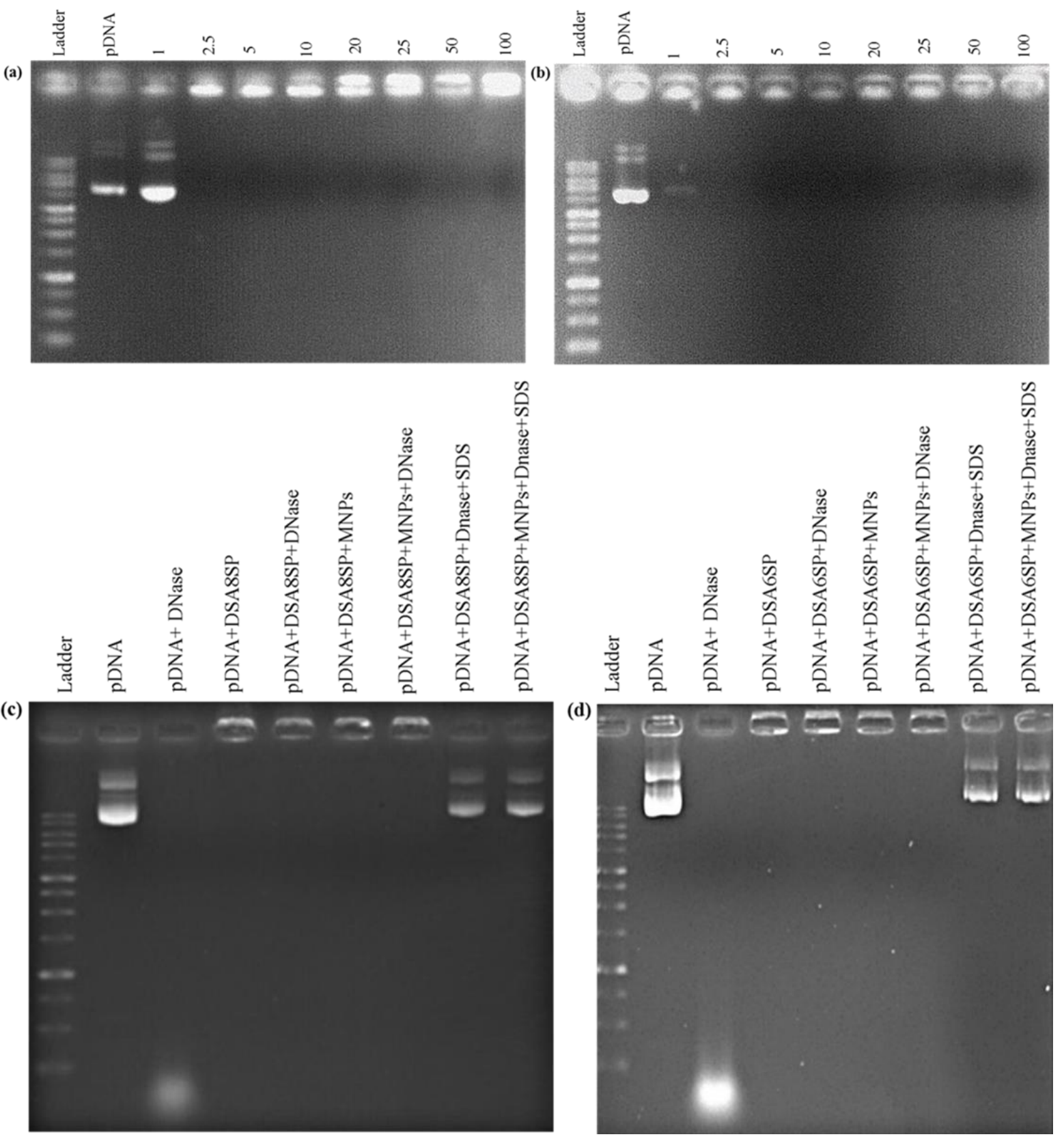

Figure 4. Gel retardation analysis of dextran-stearic acid-spermine (DSASP) on pDNA by electrostatic interaction efficacy on $1 \%$ agarose gel at different mass ratios $1,2.5,5,10,20,25,50,100 \mathrm{w} / \mathrm{w}$ of (a) DSA8SP-pDNA/MNPs and (b) DSA6SPpDNA/MNPs. Serum stability assay with DNaseI in mass ratio of $50 \mathrm{w} / \mathrm{w}$ indicates for (c) DSAsSP-pDNA/MNPs and (d) DSA6SP-pDNA/MNPs.

\subsection{The effects DSASP on cell viability in presence of SMF}

The cell viability based on the efficacy of MNPs with DS 6 ASP and DS 8 ASP was performed through MTT assay at different mass ratios in presence and absence of SMF. As shown in Figure 5, the MFs do not show any excess cytotoxicity in both nanocomplexes compared to the absence of SMF. Moreover, increasing the mass ratios of DS 8 ASP complexes, toxicity did not surge significantly $(\mathrm{P} \geq 0 / 05)$ except $100 \mathrm{w} / \mathrm{w}$ in presence of SMF, and also in some mass ratios such as $10 \mathrm{w} / \mathrm{w}$ increase in cell proliferation was estimated compared to control. In addition, in all treatments of DS 6 ASP polymer except the $100 \mathrm{w} / \mathrm{w}$, by increasing the mass ratios, no toxicity was significantly observed $(\mathrm{P} \geq 0 / 05)$. In the following treatments, the concentration of DSASP and also MNPs were prepared at $10 \mathrm{w} / \mathrm{w}$ 
and incubated in presence and absence of SMF. The results indicated no significant cytotoxicity in presence and absence of SMF compared to control after $48 \mathrm{~h}$.

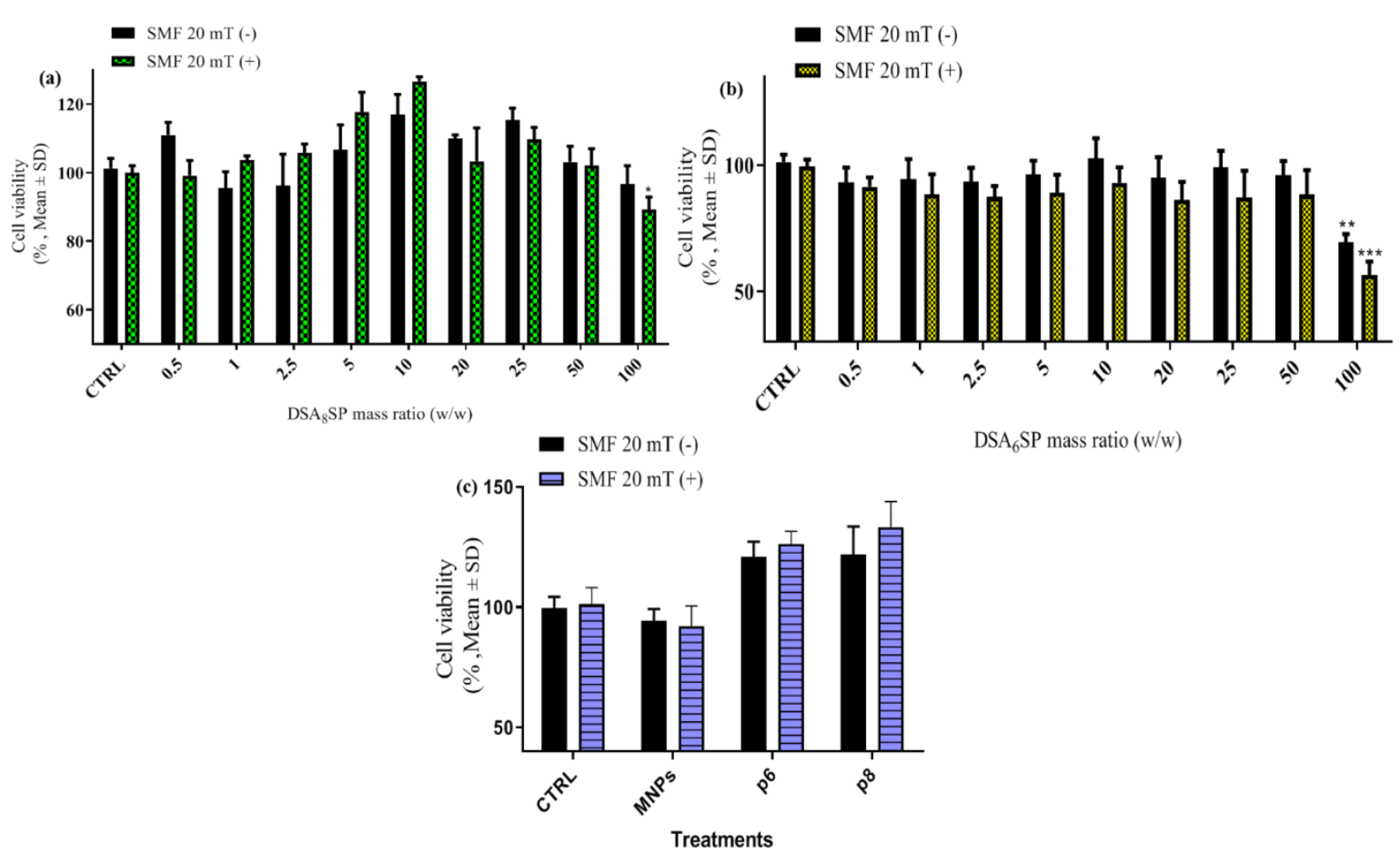

Figure 5. The effect of different mass ratios (w/w) of triplex complexes of (a) pDNA-dextran-stearic acid 8-spermine (DS8ASP)-MNPs and (b) dextran-stearic acid 6-spermine (DS6ASP) pDNA/MNP and (c) combination treatments with MNPs based on the mass ratio of $10 \mathrm{w} / \mathrm{w}$ in presence and absence of SMF $20 \mathrm{mT}$ on viability of HEK 293T cells. Data are shown as the mean \pm SD based on independent tests $(n=4) .{ }^{* *} p<0.01 ;{ }^{* * *} p<0.001$ show significant differences relative to control (CTRL), which were analyzed by one-way factorial ANOVA followed with post-hoc Newman-Keuls multiple comparison tests.

\subsection{Transfection efficiency of DSA $A_{6} S P$ and $D S A_{8} S P$ polyamines in presence $S M F$}

We transfected nucleic acids based on the magnetofection process, the DSAsSPpDNA/MNP and DSA6SP-pDNA/MNP ternary complexes were transferred to cells using an external SMF $20 \mathrm{mT}$. The ratio of polymer to DNA was determined due to different mass ratios including 10, 20, 25, 50 and $100 \mathrm{w} / \mathrm{w}$. Moreover, the amount of nanoparticles in the complex was optimized based on the weight ratio of pDNA. In different mass ratios of magnetic DSA $8 \mathrm{SP}$, an increase in luciferase activity was recorded compared to treated cell with pDNA alone. The transfection rate of the PEI as a positive control did not increase significantly compared to most mass ratios of DSA $8 \mathrm{SP}-\mathrm{pDNA} / \mathrm{MNP}$ complex ( $>0.05)$. In addition, the SMF enhanced the transfection efficiency compared to control, especially in the mass ratios of 10 and $50 \mathrm{w} / \mathrm{w}(\mathrm{P}<0.05)$ (Figure 6a). The magnetic DSA6SP polymer with different mass ratios surged the activity of luciferase significantly and also the SMF affected the transfection efficacy of polymer specifically at the mass ratio of 20 and $50 \mathrm{w} / \mathrm{w}$ $(\mathrm{P}<0.05)$. Moreover, transfection rates of magnetic nanocomplexes were higher than PEI polymer $(\mathrm{P}<0.05)$ (Figure $6 \mathrm{~b}$ ). As seen in Figure $6 \mathrm{c}$, comparison of both complexes illustrated appropriate cellular internalization as a result of a composed hydrophobic core of stearic acid, but based on a slight difference in the amount of fatty acids in polymers, the transfection efficiency of DSA6SP was higher than DSA 8 SP polymer. 

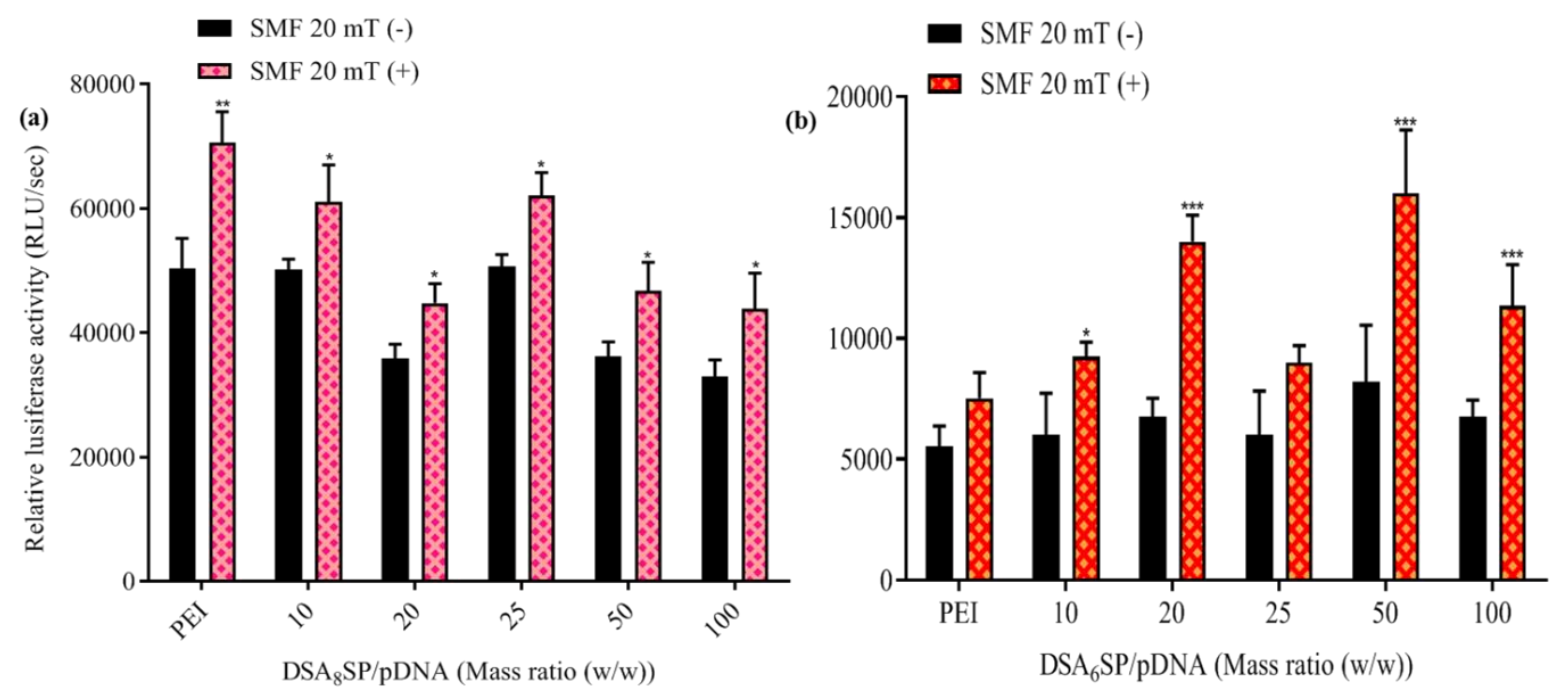

Figure 6. Evaluation the transfection efficiency of (a) dextran-stearic acid 8-spermine (DS8ASP) and (b) dextran-stearic acid 6-spermine (DS6ASP) polyamines at different mass ratios in triplex complexes based on magnetofection processes. Data are shown as the mean \pm SD based on independent tests $(n=4) .{ }^{*} p<0.05 ;{ }^{* *} p<0.01 ;{ }^{* * *} p<0.001$ show significant differences relative to cells in absence of SMF, which were analyzed by one-way factorial ANOVA followed with post-hoc Newman-Keuls multiple comparison tests.

\section{Discussion}

Several methods are used for synthesis of superparamagnetic iron oxide nanoparticles that are generally developed through two mechanisms including thermal decomposition and co-precipitation. The latter is represented to be more appropriate as it is considerably biocompatible in the in vivo conditions. Iron oxide nanoparticles are coated with biocompatible polymer for cellular transfection $[27,40]$. Here, we investigated the properties of $\mathrm{DSA}_{6} \mathrm{SP}$ and $\mathrm{DSA}_{8} \mathrm{SP}-\mathrm{Fe}_{3} \mathrm{O}_{4}$ for gene delivery in the in vitro transfection systems.

In cells, spermine due to having a considerably cationic charge, ameliorates DNA packaging into nucleus through neutralizing anionic phosphate backbone charge which leads to DNA condensation. Spermine could be applied as a valuable factor in gene delivery applications [21]. Therefore, a decrease in the size of $\mathrm{DSASP}-\mathrm{Fe}_{3} \mathrm{O}_{4}$ complex at weigh rate above $10 \mathrm{~nm}$ tend to be attributed to higher spermine rate (Figure 2c). On the other hand, different stearic acid grafted rates in DSASP amphiphilic polymer of 6 and 8 tend to be another efficient factor in polymer size rate that leads to more DNA condensation. Indeed, the natural chemical structure of stearic acid enabled molecules to be more flexible to move inward considering its free rotation of saturated carbon atoms [21]. Moreover, the surface charge of dextran-stearic acid polymers is often negative and close to zero due to the absence of ionizing groups in the dextran chains and stearic acid molecules $[15,19,22]$. Furthermore, zetasizer measurement revealed that grafts of spermine converted the zeta potential of $\mathrm{Fe}_{3} \mathrm{O}_{4}$ nanoparticles from negative into positive charges (Figure $2 \mathrm{~d}$ ). In aqueous environment, spermine residues in DSASP-NPs are localized outside the micelle formation due to its hydrophobicity property. Considering to cell membrane negatively charged, the positively charged complexes facilitate its cellular uptake [41].

Nanoparticles with critical diameter less than $25 \mathrm{~nm}$ have superparamagnetic behaviors [42]. VSM magnetization curves indicated superparamagnetic behavior with superior magnetic response for having efficient magnetofection process in both unmodified $\mathrm{Fe}_{3} \mathrm{O}_{4}$ nanoparticle and DSASP-Fe $\mathrm{O}_{4}$ complexes (Figure 2c,d). Magnetic properties of nanoparticles strongly depends on the size and shapes [42,43], because their single magnetic domain below critical diameter possess spherical structure which has parallel direction with magnetic spins that would be a reliable confirmation on SEM data and successful modification of the $\mathrm{Fe}_{3} \mathrm{O}_{4}$ MNPs by DSASP. The magnetism saturation of magnetic complexes is 
measured for 30.160 emu.g-1 relatively, being 35\% lower than $\mathrm{Fe}_{3} \mathrm{O}_{4} \mathrm{MNPs}$ at 65.3 emu.g-1 reflecting the thick amphiphilic shells covering $\mathrm{Fe}_{3} \mathrm{O}_{4}$ nanoparticles. This superparamagnetism feature is significantly recommended in the in vivo systems that prevents agglomeration of particles in the blood cycle through the removal of MFs and vanish magnetization, subsequently [42]. Results of FTIR spectra as shown in Figure 3e, represent different interactions such as coordination between $\mathrm{COO}-$ and $\mathrm{Fe}^{3+}\left(\right.$ or $\mathrm{Fe}^{2+}$ ), hydrogen bonds, Van der Waals force and electrostatic interactions which keep DSASP on the surface of magnetite nanoparticles $[38,44]$.

The issue of stability in formation of polycations-based nanocomplexes with negative phosphate backbone charge of DNA is considered as a substantial requirement in gene delivery applications to achieve proper transfection efficiency. Preparation of various weight ratio of polycations to DNA is assumed as one of the most significant parameters to achieve this process $[41,45]$. So, a different mass ratio of DSASP was mixed with similar volumes of pDNA and then results were analyzed based on gel retardation assay. The pDNA band in mass ratio of $1 \mathrm{w} / \mathrm{w}$ illustrates amphiphilic polymer inability to have efficient electrostatic interaction between amino groups and phosphate groups of DNA to entrap plasmid. Whereas, the migration of DNA, above this mass ratio was completely retarded, indicating DSASP enough cationic charge to form sustained and strong complexation with negative charge of DNA. The spermine residue conjugation on dextran molecules in DSASP polymer is considered as a factor that neutralizes the negative surface charge of DNA [45]. Moreover, the content of the spermine moieties on the dextran chain in DSA ${ }_{8} \mathrm{SP}(0.35 \mu \mathrm{mol} / \mathrm{mg})$ is higher than the other formulation based on the lower conjugation of stearic acid to polysaccharide which results in less space barrier for binding of the primary amines. Additionally, in comparison with DSA $8 \mathrm{SP}$, results show a more inconspicuous bond for gel retardation of DSA6SP polymer in $1 \mathrm{w} / \mathrm{w}$, which represents in an equal mass ratio of polymers, DSA6SP was more effective in DNA encapsulation (Figure $4 a, b)$. Higher residues of non-cationic fatty acids seem to be more effective in nucleic acid retardation compared to amine positive charges. It means, the hydrophobicity of the amphiphilic polymer, even in lower density, could neutralize a considerable fraction of the DNA charges [21].

Enzymatic degradation discussed as a restriction factor, impressively inhibits the process of gene transfection applications. Serum stability results demonstrate that although free DNA was completely digested by DNaseI due to existence of smear/fragmented band, both DSASPs encapsulated DNA were efficiently protected pDNA under enzymatic conditions attending to bright wells as an evidence for the presence of DNA which was properly capsulated in amphiphilic biopolymer (Figure 4c,d).

As DSASP polymer did not show any cytotoxicity, cell proliferation was reported in some weight ratio like $10 \mathrm{w} / \mathrm{w}$ compared to control. Additionally, by increasing the polymer mass ratio, except $100 \mathrm{w} / \mathrm{w}$, no significant cytotoxicity was observed for any DSA $8 \mathrm{SP}$ and DSA6SP magnetic complexes (Figure 5a,b). It is noticeable that the iron oxide nanoparticles, even after amphiphilic surface modification, sustained their low cytotoxicity in presence and absence of MFs (Figure 5c). The polyamines like spermine are fundamental factors in the cell proliferation cycle which naturally exist in cells $[19,46]$. Indeed, although spermine's increasing rate provides grounds to accelerate cell proliferation and restrict apoptosis by inhibiting cytochrome c release, its intracellular depletion leads cellular growth to be arrested [46].

Decrease in time association of nucleic acids with enzymatic conditions in cells and/or serum by the aim of accelerating DNA agglomeration to targeted cells and intensifying its rapid physical transportation, is demonstrated as another impressive factor in DNA protection which is studied through magnetofection [32]. Magnetofection through applying the external MF is considered as a non-invasive therapeutic approach, leading to cell viability without disrupting plasma membranes [23]. It is clearly shown that incubation with the application of a magnetic field in cell culture media remarkably reinforces cellular efficiency of complex for all DSASP-pDNA/MNPs, especially at weight ratio of 50 and $10 \mathrm{w} / \mathrm{w}$ in DSA 6 SP and also 50 and 20 in DSA 8 SP (Figure 6). However, DSA6P- 
pDNA/ $\mathrm{Fe}_{3} \mathrm{O}_{4}$ nanoparticles show a preferable transfection efficacy presumably based on higher stearic acid residues which result in better condensation of complexes (Figure 6b). DSA 6 SP with higher grafted rate of stearic acid (20\%), gradually restricted more spermine conjugation with dextran chain which its amine content was evaluated at $0.26 \mu \mathrm{mol} / \mathrm{mg}$ as well as $0.35 \mu \mathrm{mol} / \mathrm{mg}$ and also $15 \%$ stearic acid in DSA 8 SP.

Spermine residues conjugated on dextran make it a more appropriate biodegradable polycations for gene delivery applications [47]. Moreover, based on our obtained results, the addition of both spermine and stearic acid conjugations along the dextran chain, affect the DNA-binding complex transfection efficiency and density, significantly. Hosseinkhani et al., considered stable interactions with various cationic polysaccharide derivatives and different grafts of oligoamines, only dextran-spermine polycations found active in transfection assay [47]. Additionally, the emphasis of grafted spermine moieties in transfection efficiency was represented properly by the study of Azzam et al., to point out the spermine residues high buffering capacity. Therefore, the more spermine incorporation in dextran-spermine compound, the more luciferase expression [14]. Furthermore, spermine could promote DNA condensation and simplify endo-lysosomal escape of oligonucleotide with two primary and two secondary amino groups respectively which results in an efficient transfection rate [19].

\section{Conclusions}

In conclusion, conjugation of fatty acids to polycations are utilized to protect the coated DNA-polymer complex from enzymes and ease the cellular uptake of amphiphilic complex into lipophilic plasma membrane based on hydrophobic surface [14]. Particle size in amphiphilic polymers, was directly affected by hydrophobic to hydrophilic chain ratios. So, the enhancement of stearic acid conjugation degree in amphiphilic structure simultaneously leads to increase in polymer hydrophobic properties, closer polymeric interactions in aqueous medium and assembly of smaller particles. Indeed, decreasing the size will subsequently increase the surface/volume ratio of particles. These phenomena lead more particles to communicate and destabilized the aqueous medium [22]. Therefore, through higher association of stearic acid with dextran in DSASP-pDNA/Fe $\mathrm{O}_{4}$ complexes, the surface/volume ratio increases alongside decreasing complex size which consequent more hydrophobic interaction with plasma membrane. Considering DSA $8 \mathrm{SP}$ with more amine content and also the efficient role of positive charges, the lower transfection efficacy was represented for this carrier compared to DSA6SP. Finally, the importance of hydrophilic content in transfection assay is explained based on the efficient effects on total size of complexes and enhancement of their cellular attachment due to plasma cell membranes.

Author Contributions: “Conceptualization, M.S. and P.A.; methodology, B.H.V. and M.S.; software, M.K.A.; validation, B.H.V., M.S. and S.H.; formal analysis, M.S. and S.H; investigation, M.K.A.; resources, P.A. and S.H.; writing-original draft preparation, M.K.A.; writing-review and editing, M.K.A., B.H.V, P.A. and S.H.; supervision, P.A.; project administration, B.H.V., M.S. and S.H. All authors have read and agreed to the published version of the manuscript.

Funding: This research received no external funding.

Data Availability Statement: The data presented in this study are available on request from the corresponding author.

Acknowledgments: We thank Dr. Ebrahim Vasheghani-Farahani (Chemical Engineering, Tarbiat Modares University) and Hossein Shaki (Chemical Engineering, Tarbiat Modares University) for their contributions in this study. We would also like to appreciate Research Council of Tarbiat Modares University

Conflicts of Interest: The authors declare no conflict of interest.

\section{References}

1. Gozuacik, D.; Yagci-Acar, H.; Akkoç, Y.; Kosar, A.; Dogan-Ekici, A.I.; Ekici, S. Anticancer use of nanoparticles as nucleic acid carriers. Journal of biomedical nanotechnology 2014, 10, 1751-1783. 
2. Sudhakar, A. History of cancer, ancient and modern treatment methods. Journal of cancer science $\mathcal{E}$ therapy $2009,1,1$.

3. Eliyahu, H.; Makovitzki, A.; Azzam, T.; Zlotkin, A.; Joseph, A.; Gazit, D.; Barenholz, Y.; Domb, A. Novel dextran-spermine conjugates as transfecting agents: comparing water-soluble and micellar polymers. Gene therapy 2005, 12, 494-503.

4. Schaffer, D.V.; Lauffenburger, D.A. Optimization of cell surface binding enhances efficiency and specificity of molecular conjugate gene delivery. Journal of Biological Chemistry 1998, 273, 28004-28009.

5. $\quad$ Teixeira, H.F.; Bruxel, F.; Fraga, M.; Schuh, R.S.; Zorzi, G.K.; Matte, U.; Fattal, E. Cationic nanoemulsions as nucleic acids delivery systems. International journal of pharmaceutics 2017, 534, 356-367.

6. Wong, S.Y.; Pelet, J.M.; Putnam, D. Polymer systems for gene delivery - past, present, and future. Progress in Polymer Science 2007, 32, 799-837.

7. Cho, K.; Wang, X.; Nie, S.; Shin, D.M. Therapeutic nanoparticles for drug delivery in cancer. Clinical cancer research 2008, 14 , 1310-1316.

8. Mykhaylyk, O.; Antequera, Y.S.; Vlaskou, D.; Plank, C. Generation of magnetic nonviral gene transfer agents and magnetofection in vitro. Nature protocols 2007, 2, 2391.

9. Yin, H.; Kanasty, R.L.; Eltoukhy, A.A.; Vegas, A.J.; Dorkin, J.R.; Anderson, D.G. Non-viral vectors for gene-based therapy. Nature Reviews Genetics 2014, 15, 541-555.

10. Ye, S.; Cole-Strauss, A.; Frank, B.; Kmiec, E.B. Targeted gene correction: a new strategy for molecular medicine. Molecular medicine today 1998, 4, 431-437.

11. Nóbrega, C.; Mendonça, L.; Matos, C.A. A Handbook of Gene and Cell Therapy; Springer: 2020.

12. Sohrabijam, Z.; Saeidifar, M.; Zamanian, A. Enhancement of magnetofection efficiency using chitosan coated superparamagnetic iron oxide nanoparticles and calf thymus DNA. Colloids and Surfaces B: Biointerfaces 2017, 152, 169-175.

13. Putnam, D.; Gentry, C.A.; Pack, D.W.; Langer, R. Polymer-based gene delivery with low cytotoxicity by a unique balance of side-chain termini. Proceedings of the National Academy of Sciences 2001, 98, 1200-1205.

14. Azzam, T.; Eliyahu, H.; Makovitzki, A.; Linial, M.; Domb, A.J. Hydrophobized dextran-spermine conjugate as potential vector for in vitro gene transfection. Journal of Controlled Release 2004, 96, 309-323.

15. Li, S.; Yi, J.; Li, W.; Wang, L.; Wang, Z. Synthesis and characterization of three novel amphiphilic dextran self-assembled micelles as potential drug delivery system. Journal of Materials Science 2017, 52, 12593-12607.

16. Hosseinkhani, H.; He, W.-J.; Chiang, C.-H.; Hong, P.-D.; Yu, D.-S.; Domb, A.J.; Ou, K.-L. Biodegradable nanoparticles for gene therapy technology. Journal of nanoparticle research 2013, 15, 1-15.

17. Su, H.; Liu, Y.; Wang, D.; Wu, C.; Xia, C.; Gong, Q.; Song, B.; Ai, H. Amphiphilic starlike dextran wrapped superparamagnetic iron oxide nanoparticle clsuters as effective magnetic resonance imaging probes. Biomaterials 2013, 34, 1193-1203.

18. Ghadiri, M.; Vasheghani-Farahani, E.; Atyabi, F.; Kobarfard, F.; Hosseinkhani, H. In-vitro assessment of magnetic dextranspermine nanoparticles for capecitabine delivery to cancerous cells. Iranian journal of pharmaceutical research: IJPR 2017, 16, 1320.

19. Meng, T.; Wu, J.; Yi, H.; Liu, J.; Lu, B.; Yuan, M.; Huang, X.; Yuan, H.; Hu, F. A spermine conjugated stearic acid-g-chitosan oligosaccharide polymer with different types of amino groups for efficient p53 gene therapy. Colloids and Surfaces B: Biointerfaces 2016, 145, 695-705.

20. Azzam, T.; Eliyahu, H.; Makovitzki, A.; Domb, A. Dextran-spermine conjugate: an efficient vector for gene delivery. In Proceedings of Macromolecular Symposia; pp. 247-262.

21. Liu, Z.; Zhang, Z.; Zhou, C.; Jiao, Y. Hydrophobic modifications of cationic polymers for gene delivery. Progress in Polymer Science 2010, 35, 1144-1162.

Shaki, H.; Ganji, F.; Kempen, P.J.; Dolatshahi-Pirouz, A.; Vasheghani-Farahani, E. Self-assembled amphiphilic-dextran nanomicelles for delivery of rapamycin. Journal of Drug Delivery Science and Technology 2018, 44, 333-341.

Alvizo-Baez, C.A.; Luna-Cruz, I.E.; Vilches-Cisneros, N.; Rodríguez-Padilla, C.; Alcocer-González, J.M. Systemic delivery and activation of the TRAIL gene in lungs, with magnetic nanoparticles of chitosan controlled by an external magnetic field. International journal of nanomedicine 2016, 11, 6449.

24. Dobson, J. Gene therapy progress and prospects: magnetic nanoparticle-based gene delivery. Gene therapy 2006, 13, $283-287$.

25. Mohammad-Taheri, M.; Vasheghani-Farahani, E.; Hosseinkhani, H.; Shojaosadati, S.A.; Soleimani, M. Fabrication and characterization of a new MRI contrast agent based on a magnetic dextran-spermine nanoparticle system. Iranian Polymer Journal 2012, 21, 239-251.

26. Qu, J.; Liu, G.; Wang, Y.; Hong, R. Preparation of Fe3O4-chitosan nanoparticles used for hyperthermia. Advanced Powder Technology 2010, 21, 461-467.

27. Wu, W.; He, Q.; Jiang, C. Magnetic iron oxide nanoparticles: synthesis and surface functionalization strategies. Nanoscale research letters 2008, 3, 397-415.

28. Rasouli, E.; Basirun, W.J.; Rezayi, M.; Shameli, K.; Nourmohammadi, E.; Khandanlou, R.; Izadiyan, Z.; Sarkarizi, H.K. Ultrasmall superparamagnetic $\mathrm{Fe} 3 \mathrm{O} 4$ nanoparticles: honey-based green and facile synthesis and in vitro viability assay. International journal of nanomedicine 2018, 13, 6903.

29. Scott, V.; Clark, A.R.; Docherty, K. The gel retardation assay. Protocols for gene analysis 1994, 339-347. 
30. Magdeldin, S. Gel electrophoresis: Principles and basics; BoD-Books on Demand: 2012.

31. Schnurr, B.; Ahrens, T.; Regenass, U. Optical assays in drug discovery. 2007.

32. Namgung, R.; Singha, K.; Yu, M.K.; Jon, S.; Kim, Y.S.; Ahn, Y.; Park, I.-K.; Kim, W.J. Hybrid superparamagnetic iron oxide nanoparticle-branched polyethylenimine magnetoplexes for gene transfection of vascular endothelial cells. Biomaterials 2010, 31, 4204-4213.

33. Yu, Y.; Hu, Y.; Li, X.; Liu, Y.; Li, M.; Yang, J.; Sheng, W. Spermine-modified Antheraea pernyi silk fibroin as a gene delivery carrier. International journal of nanomedicine 2016, 11, 1013.

34. Tauxe, L.; Mullender, T.; Pick, T. Potbellies, wasp-waists, and superparamagnetism in magnetic hysteresis. Journal of Geophysical Research: Solid Earth 1996, 101, 571-583.

35. El Ghandoor, H.; Zidan, H.; Khalil, M.M.; Ismail, M. Synthesis and some physical properties of magnetite (Fe3O4) nanoparticles. Int. J. Electrochem. Sci 2012, 7, 5734-5745.

36. Mohamed, M.A.; Jaafar, J.; Ismail, A.; Othman, M.; Rahman, M. Fourier transform infrared (FTIR) spectroscopy. In Membrane Characterization, Elsevier: 2017; pp. 3-29.

37. ur Rahman, O.; Mohapatra, S.C.; Ahmad, S. Fe3O4 inverse spinal super paramagnetic nanoparticles. Materials Chemistry and Physics 2012, 132, 196-202.

38. 38. Cao, H.; Li, J.; Shen, Y.; Li, S.; Huang, F.; Xie, A. Green synthesis and surface properties of Fe3O4@ SA core-shell nanocomposites. Applied surface science 2014, 301, 244-249.

39. Mistry, B. A handbook of spectroscopic data. Chemistry 2009.

40. Tassa, C.; Shaw, S.Y.; Weissleder, R. Dextran-coated iron oxide nanoparticles: a versatile platform for targeted molecular imaging, molecular diagnostics, and therapy. Accounts of chemical research 2011, 44, 842-852.

41. Cen, C.; Wu, J.; Zhang, Y.; Luo, C.; Xie, L.; Zhang, X.; Yang, X.; Li, M.; Bi, Y.; Li, T. Improving magnetofection of magnetic polyethylenimine nanoparticles into MG-63 osteoblasts using a novel uniform magnetic field. Nanoscale research letters 2019, 14, 1-14.

42. Estelrich, J.; Escribano, E.; Queralt, J.; Busquets, M.A. Iron oxide nanoparticles for magnetically-guided and magneticallyresponsive drug delivery. International journal of molecular sciences 2015, 16, 8070-8101.

43. Lee, H.; Nguyen, Y.; Muthiah, M.; Vu-Quang, H.; Namgung, R.; Kim, W.; Yu, M.; Jon, S.; Lee, I.; Jeong, Y. MR traceable delivery of p53 tumor suppressor gene by PEI-functionalized superparamagnetic iron oxide nanoparticles. Journal of biomedical nanotechnology 2012, 8, 361-371.

44. Predescu, A.M.; Matei, E.; Berbecaru, A.C.; Pantilimon, C.; Drăgan, C.; Vidu, R.; Predescu, C.; Kuncser, V. Synthesis and characterization of dextran-coated iron oxide nanoparticles. Royal Society open science 2018, 5, 171525.

45. Amini, R.; Jalilian, F.A.; Abdullah, S.; Veerakumarasivam, A.; Hosseinkhani, H.; Abdulamir, A.; Domb, A.; Ickowicz, D.; Rosli, R. Dynamics of PEGylated-dextran-spermine nanoparticles for gene delivery to leukemic cells. Applied biochemistry and biotechnology 2013, 170, 841-853.

46. Holst, C.M.; Oredsson, S.M. Comparison of three cytotoxicity tests in the evaluation of the cytotoxicity of a spermine analogue on human breast cancer cell lines. Toxicology in vitro 2005, 19, 379-387.

47. Hosseinkhani, H.; Azzam, T.; Tabata, Y.; Domb, A. Dextran-spermine polycation: an efficient nonviral vector for in vitro and in vivo gene transfection. Gene therapy 2004, 11, 194-203. 